\title{
Production of cross neutralizing single chain fragment variables (scFv) from HIV-1 infected Indian children
}

\author{
Sanjeev Kumar ${ }^{1}$, Rajesh Kumar ${ }^{1}$, Muzamil Makhdoomi ${ }^{1}$, Lubina Khan ${ }^{1}$, SS Prakash', \\ Ramachandran Thiruvengadam ${ }^{1}$, Mohit Singla ${ }^{2}$, Rakesh Lodha ${ }^{2}$, SK Kabra ${ }^{2}$, Subrata Sinha ${ }^{3}$, Kalpana Luthra ${ }^{1 *}$
}

From 2nd International Science Symposium on HIV and Infectious Diseases (HIV SCIENCE 2014)

Chennai, India. 30 January - 1 February 2014

\section{Background}

Monoclonal antibody based vaccines are effective and highly specific in disease targeting. Presently, most of the existing broadly neutralizing antibodies are generated against non subtype $\mathrm{c}$ viruses. HIV-1 subtype $\mathrm{c}$ accounts for more than $90 \%$ of infection in India. The disease progression in children is faster than adults.

\section{Methods}

Nine ART drug naïve HIV-1 subtype c infected children were recruited. PBMCs were isolated from all the subjects and pooled. RNA was isolated and cDNA was synthesized followed by amplification of $\mathrm{VH}$ and $\mathrm{VL}$ chain genes and $\mathrm{scFv}$ construction. A human recombinant scFv phage display library of 108 clones was constructed. Diversity of the phage library was checked by DNA sequencing and biopanned with RSC3 core antigen. 60 random clones were screened by phage ELISA. Expression of the scFvs was assessed by SDS-PAGE and Western blotting.

\section{Results}

The diversity of the phage library was more than $90 \%$. Eight scFv monoclonals showed positive binding in phage ELISA and two best binders were further characterized. Both scFvs didn't show any reactivity with unrelated antigens. DNA fingerprinting analysis showed both scFvs were distinct. A $32 \mathrm{kDa}$ band was obtained in SDS-PAGE and Western blot. Both scFvs showed cross neutralizing activity against a standard panel of pseudoviruses.

\footnotetext{
* Correspondence: kalpanaluthra@gmail.com

1 Department of Biochemistry, All India Institute of Medical Sciences (AlIMS), New Delhi, India

Full list of author information is available at the end of the article
}

\section{Conclusion}

Here, we have for the first time generated a human recombinant $\mathrm{scFv}$ phage display library containing neutralizing clones from HIV-1 infected children. Further characterization of these scFvs generated against CD4 binding site for their epitope mapping would be helpful in the development of an effective HIV-1 vaccine.

\section{Authors' details \\ ${ }^{1}$ Department of Biochemistry, All India Institute of Medical Sciences (AllMS), New Delhi, India. ${ }^{2}$ Department of Pediatrics, All India Institute of Medical Sciences (AllMS), New Delhi, India. ${ }^{3}$ National Brain Research Centre (NBRC), Gurgaon, Haryana, India.}

Published: 27 May 2014

doi:10.1186/1471-2334-14-S3-E25

Cite this article as: Kumar et al.: Production of cross neutralizing single chain fragment variables (scFv) from HIV-1 infected Indian children. BMC Infectious Diseases 2014 14(Suppl 3):E25.

Submit your next manuscript to BioMed Central and take full advantage of:

- Convenient online submission

- Thorough peer review

- No space constraints or color figure charges

- Immediate publication on acceptance

- Inclusion in PubMed, CAS, Scopus and Google Scholar

- Research which is freely available for redistribution

Submit your manuscript at www.biomedcentral.com/submit
() Biomed Central 